\title{
Noncoding RNAs and the control of hormonal signaling via nuclear receptor regulation
}

\section{Silvia Ottaviani, Alexander de Giorgio, Victoria Harding, Justin Stebbing and Leandro Castellano}

Department of Surgery and Cancer, Imperial College London, Imperial Centre for Translational and Experimental Medicine, London W12 0NN, UK

Abstract

Despite its identification over 100 years ago, new discoveries continue to add to the complexity of the regulation of the endocrine system. Today the nuclear receptors (NRs) that play such a pivotal role in the extensive communication networks of hormones and gene expression remain an area of intense research. By orchestrating core processes, from metabolism to organismal development, the gene expression programs they control are dependent on their cellular context, their own levels, and those of numerous co-regulatory proteins. A previously unknown component of these networks, noncoding RNAs (ncRNAs) are now recognized as potent regulators of NR signaling, influencing receptor and co-factor levels and functions while being reciprocally regulated by the NRs themselves. This review explores the regulation enacted by microRNAs and long ncRNAs on NR function, using representative examples to show the varied roles of ncRNAs, in turn producing significant

effects on the NR functional network in health and disease.
\end{abstract}

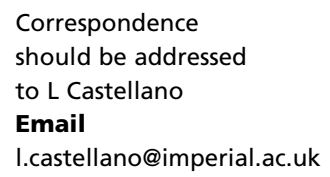

\section{Introduction}

Advances in high-throughput sequencing techniques have revealed eukaryotic genomes to be extensively transcribed, generating an array of novel non-proteincoding RNA classes that greatly outnumber protein-coding mRNAs (Carninci et al. 2005, Birney et al. 2007, Kapranov et al. 2007, Bernstein et al. 2012, Djebali et al. 2012). Noncoding RNAs (ncRNAs) encompass numerous functional classes including tRNA, rRNA, small nuclear RNA, and small nucleolar RNA, widely recognized to play pivotal roles in cell function (reviewed in Matera et al. (2007)). More recently, new and potent classes of regulatory RNAs have been discovered. These classes are composed of small RNAs, most prominently the microRNAs (miRNAs), as well as the long ncRNAs (lncRNAs) defined as being over 200 nucleotides (nt) but ranging to above 10000 -nt. In succession, these discoveries have created new fields in cell biological research, exploring the ability of ncRNAs to regulate the expression of biologically significant genes. It soon became clear that they have the capacity to modulate most important biological processes (Hirose et al. 2014), which in turn makes these ncRNAs a focus of interest within health and disease research (Batista \& Chang 2013).

miRNAs make up a populous class of small ncRNAs, with more than 2000 human miRNA genes annotated to date in the miRNA database, miRBase (http://www. mirbase.org). Most miRNAs are transcribed as long miRNA primary transcripts (pri-miRNAs) by RNA polymerase II (Pol II) (Lee et al. 2004), which then undergo a canonical biogenic process characterized by two 
sequential enzymatic cleavage steps. The first occurs in the nucleus by the nuclear RNAse III enzyme Drosha and the second in the cytoplasm by a second RNAse III enzyme, Dicer. This maturation process generates the final mature molecules which are loaded onto the miRNA-induced silencing complex, composed of Argonaute (Ago) proteins (reviewed in Krol et al. (2010)). Mature miRNAs are approximately 22-nt single-stranded RNA molecules that mediate post-transcriptional regulation of gene expression either by inhibiting translation or by promoting destabilization of target mRNAs through deadenylation (Fabian et al. 2010, Krol et al. 2010). In mammals, miRNAs regulate post-transcriptional gene expression by partial complementary binding to their targets, but with full complementary pairing within a limited region of six to eight nt in length at the $5^{\prime}$ end of the miRNA, named the 'seed' region (Lewis et al. 2005, Bartel 2009). The perfect complementarity between the miRNA seed region and target mRNAs is considered to be the major determinant of miRNA target specificity and regulation. However, many studies have also reported noncanonical modulation of targets, which can occur with mismatches within the seed region or the central region of the miRNA (Bartel 2009, Shin et al. 2010, Helwak et al. 2013).

The IncRNAs are an emerging class of key regulatory ncRNAs that have already been implicated in a range of cellular processes (Wapinski \& Chang 2011, Rinn \& Chang 2012). Similar to mRNAs, IncRNAs are mostly transcribed by RNA Pol II, undergo 5 '-capping, and usually 3 '-polyadenylation and splicing, although diverse unspliced and non-3'-polyadenylated lncRNAs have been described. Unlike mRNAs, IncRNAs have very little or no potential to encode proteins, and although the extent of their coding capacity remains under investigation, results from ribosome profiling experiments indicate that most occupancy of ribosomes by lncRNAs mirrors that of $5^{\prime}$-UTRs and fails to produce functional peptides (Guttman et al. 2013). Nevertheless, three groups independently identified peptides encoded by such molecules with specific cellular functions (Magny et al. 2013, Bazzini et al. 2014, Pauli et al. 2014). Some lncRNAs are located between protein-coding genes and termed long intergenic RNAs (lincRNAs), while many others can be transcribed from within the coding genes or in an antisense orientation to mRNAs. The IncRNAs regulate gene expression through an expanding number of defined mechanisms. The relative flexibility of RNA molecules may enable them to function as modular scaffolds, with different sections of a lncRNA binding various protein, DNA, and RNA substrates, to carry out specific functions in combination (Guttman \& Rinn 2012, Mercer \& Mattick 2013).

Nuclear receptors (NRs) are ligand-activated transcription factors that regulate gene expression by binding to regulatory regions in the genomic DNA. NRs are critically involved in an array of physiological processes including growth, differentiation, homeostasis, development, and metabolism (Mangelsdorf et al. 1995). Conversely, dysregulated NR signaling participates in a range of pathological processes, with NRs implicated in diseases such as diabetes, hormone resistance syndromes, and cancer. Forty-eight NRs have been identified in humans (Xiao et al. 2013). Upon ligand binding, these receptors interact with specific DNA sequences in the promoter and enhancer regions of their target genes. The transcription of regulated genes is modulated by co-binding of an array of co-factors as well as RNA polymerases and several components of the transcription initiation machinery (Acevedo \& Kraus 2004, Cheung \& Kraus 2010, Hah et al. 2011). Based on ligand properties, the NR superfamily can be broadly divided into three classes: hormone, metabolic, and orphan NRs (Gadaleta \& Magnani 2014). The hormone receptor subfamily includes the estrogen receptors $(E R \alpha(E S R 1)$ and $E R \beta$ (ESR2)), androgen receptor $(\mathrm{AR})$, progesterone receptor (PR), glucocorticoid receptor (GR), and mineralocorticoid receptor (MR) (Mangelsdorf et al. 1995). In terms of structural organization, NRs share a modular structure composed of four domains: an $\mathrm{N}$-terminal activation domain, a DNA-binding domain (DBD), a small hinge region, and a C-terminal ligandbinding domain (LBD) (Helsen \& Claessens 2014). Hormone NRs bind to DNA primarily as homodimers. The DBD consists of two zinc finger domains in which a zinc atom is coordinated by four cysteine residues (Helsen et al. 2012). The first zinc finger contains a conserved motif known as the 'P-box' that coordinates base-specific interactions within the DNA major groove. The second zinc finger contains another conserved motif, the 'D-box', which forms the dimerization interface (Zechel et al. 1994). Hormone NRs have long been known to bind to DNA elements that are arranged as inverted repeats of hexameric motifs separated by three nucleotide spacers. For $\mathrm{AR}, \mathrm{PR}, \mathrm{GR}$, and $\mathrm{MR}$, the consensus hexamer is $5^{\prime}$-AGAACA-3'. For ERs, the consensus is $5^{\prime}$-AGGTCA-3' (Carroll et al. 2006). In addition, $\mathrm{AR}$ and $\mathrm{PR}$ can also bind to direct repeats of the 5'-AGAACA-3' motifs (Denayer et al. 2010, Kerkhofs et al. 2012). Recently, chromatin immunoprecipitation coupled with massively parallel DNA sequencing (ChIP-seq) has allowed detailed mapping of NR-binding sites across the whole genome

Published by Bioscientifica Ltd. 
and has revealed a strong preference for hormone NRs to bind regions of the genome that are distal from transcription start sites of coding genes $(>10 \mathrm{~kb}$ ) (Carroll et al. 2005, Wang et al. 2007). These studies have also shown enrichment for binding motifs of other transcription factors, indicating that NRs can bind to DNA indirectly through interaction with other transcription factors (Heldring et al. 2011, Sahu et al. 2011). Furthermore, it has been shown that multiple NRs can bind to the same genomic locus, indicating an important crosstalk between different NR signaling pathways through cooperative or antagonistic interactions (Ross-Innes et al. 2010, Lai et al. 2013).

Many factors contribute to the regulation of NRs ultimately enhancing/repressing transcription of target genes; these include the recruitment of co-regulatory proteins, post-translational modifications and interactions with other transcription factors. ncRNAs represent an additional layer of complexity in the network that governs NR-dependent gene expression. By turning our attention to the effects of miRNAs and later lncRNAs on NR function in the specific case of hormonal signaling, we highlight recent advances in our understanding of these processes and discuss the capacity of ncRNAs to act at multiple regulatory levels to fine-tune NR function.

\section{miRNAs and NRs}

The interplay between miRNAs and NRs is complex and is represented by a network of feedback and feed-forward regulatory loops. NRs can regulate the expression and/or biogenesis of miRNAs, and, conversely miRNAs regulate NR signaling by targeting NRs and/or co-regulatory proteins (Cochrane et al. 2011). In the following sections, we discuss the main features of this crosstalk.

\section{miRNAs and ER $\alpha$}

Many studies in recent years have shown that estrogens, through the action of $\mathrm{ER} \alpha$, can modulate the levels of pri-miRNA transcription (Fig. 1A). This regulation can occur through at least two main mechanisms: ER $\alpha$ can directly bind to the regulatory regions of miRNAs or estrogen can regulate the expression of transcription factors that control the expression of miRNAs (reviewed in Cochrane et al. (2011)). By generating and analyzing a miRNA expression microarray for ER $\alpha$-positive MCF-7 breast cancer cells treated with $17 \beta$-estradiol $\left(\mathrm{E}_{2}\right)$, we have previously shown that the expression of the human mir-17-92 cluster and its paralogous clusters, along with
A

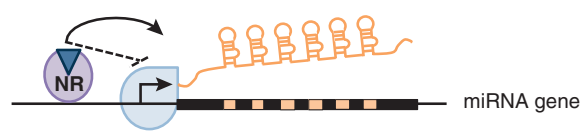

B

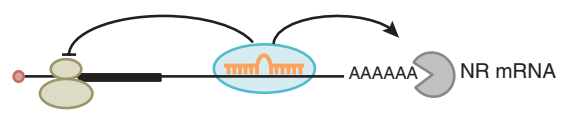

C

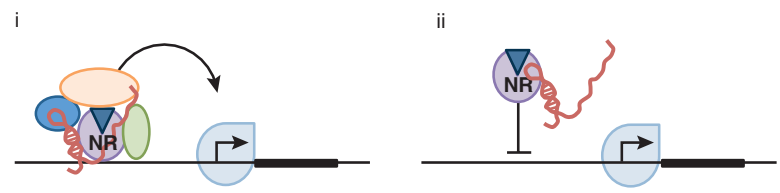

iii

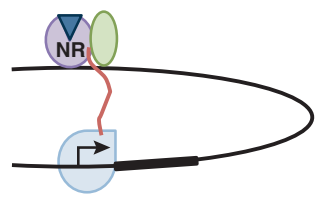

D

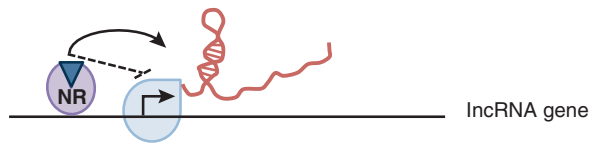

Figure 1

Schematic representation of the crosstalk regulation between ncRNAs and NRs. (A) NRs can regulate the transcription of miRNA genes (the figure depicts a unique transcript containing several miRNAs). (B) miRNAs can bind to the $3^{\prime}$-UTR of NR transcripts and post-transcriptionally regulate them. (C) IncRNAs can modulate NR activity through different mechanisms: IncRNAs can bind to NRs and other proteins, acting as scaffolds (e.g., SRA), (i) they can bind to NRs and prevent them from binding to DNA, thereby acting as decoys (e.g., GAS5) (Carninci et al. 2005) (ii) or they can be transcribed from NR enhancers and participate in chromosomal looping (iii). (D) NRs can regulate transcription the of IncRNA genes.

the expression of miRNAs encoded by these clusters, are induced by $\mathrm{E}_{2}$ treatment. In addition, we showed that the regulation occurs indirectly through binding of the $\mathrm{E}_{2}$ induced transcription factor c-MYC to the promoter of the cluster (Castellano et al. 2009). Similarly, Bhat-Nakshatri et al. (2009) have reported that $\mathrm{E}_{2}$ induces the expression of the Let7 family of miRNAs as well as other miRNAs including miR-21, whose expression is regulated by direct binding of $\mathrm{ER} \alpha$ to its promoter region. In a later study, we showed that $\mathrm{ER} \alpha$, through the direct transcriptional downregulation of miR-515-5p, regulates cell proliferation, at least in part, by targeting the sphingosine kinase 1 (SK1) oncogene (Pinho et al. 2013). In addition to regulating the expression of miRNAs at the level of transcription, ER $\alpha$ can regulate miRNA processing. Indeed, several proteins involved in miRNA biogenesis, including Dicer and the

Published by Bioscientifica Ltd 
component of RISC complex Ago2, are induced by $\mathrm{E}_{2}$ and their levels differ in ER $\alpha$-positive and -negative breast cancers (Adams et al. 2009, Bhat-Nakshatri et al. 2009, Cheng et al. 2009).

Conversely, miRNAs can directly target the $3^{\prime}$-UTR of the ER $\alpha$ transcript itself and/or the 3'-UTRs of co-regulatory proteins (Fig. 1B). In some cases, the crosstalk between miRNAs and ER $\alpha$ is in the form of a negative feedback loop. For example, miR-18a, miR-19b, and miR-20b encoded by the $\mathrm{E}_{2}$-induced mir-17-92 cluster and/or paralogues directly target the ER $\alpha 3^{\prime}$-UTR, causing downregulation of ER $\alpha$ expression at the protein level (Castellano et al. 2009). Furthermore, miR-20b targets and downregulates the ER $\alpha$ co-activator AIB1, demonstrating the capacity of such miRNA clusters to fine-tune at multiple points in the same pathway (Castellano et al. 2009). In addition to our work, results from several other studies have indicated that miRNAs can directly target the $\mathrm{ER} \alpha$ transcript, including miR-206, the first to be identified (Adams et al. 2007), and miR-221/222 (Zhao et al. 2008). More recently, Leivonen et al. (2009) used a protein lysate microarray technology to systematically identify miRNAs that target the ER $\alpha$ 3'-UTR, providing a comprehensive picture of previously characterized, as well as novel ER $\alpha$-targeting miRNAs.

\section{miRNAs and AR}

Similarly to the scenario described earlier, androgens through the action of AR can regulate the transcriptional output from miRNA loci. Expression profiling studies in prostate cancer have identified an array of androgen upand down-regulated miRNAs potentially involved in prostate cancer progression (Porkka et al. 2007, Ambs et al. 2008, Ozen et al. 2008, Waltering et al. 2011). Several miRNAs have been experimentally characterized and proven to be directly involved in AR signaling and consequently in prostate cancer. They are regulated by $\mathrm{AR}$ and have been shown to act as both oncogenes (oncomirs), including miR-21 (Ribas et al. 2009), miR125b (Shi et al. 2007), miR-141 (Waltering et al. 2011, Xiao et al. 2012), miR-27a (Fletcher et al. 2012), and as tumor suppressor genes as in the case of miR-205 (Hulf et al. 2013). Interestingly, miR-205 plays an important role in counteracting epithelial-to-mesenchymal transition by targeting ZEB1 and ZEB2, both negative regulators of E-cadherin expression (Gregory et al. 2008, Gandellini et al. 2009). In addition, it has been shown that circulating levels of miRNAs that are upregulated in prostate cancer, as in the case of miR-141, are increased in prostate cancer patients compared with healthy controls, indicating a potential use of these ncRNAs as novel biomarkers for this disease (Mitchell et al. 2008, Brase et al. 2011). Compared with ER $\alpha$, the $3^{\prime}$-UTR of AR transcript is considerably shorter, and accordingly fewer miRNAs have been predicted to interact with it. A recent study, using a protein lysate microarray combined with $3^{\prime}$-UTR luciferase reporter assays in a panel of prostate cancer cell lines, has identified 13 miRNAs that target and repress the AR transcript (Ostling et al. 2011).

\section{miRNAs and other NRs}

In addition to estrogens and androgens, other hormones through the action of their cognate NR can regulate miRNA expression, further indicating the important role of miRNAs in NR signaling. Progesterone, through the action of PR, can regulate the expression of numerous miRNAs, including the miR-200 family (Renthal et al. 2010), let-7 (Wendler et al. 2011), and miR-320 (Xia et al. 2010). Glucocorticoids, by activating both GR and MR NRs, have been reported to upregulate miR-15/16 clusters in leukemia cell lines and prostrate cancer patients (Rainer et al. 2009). In addition, the 3'-UTR of these NRs can be targeted by miRNAs; however, compared with ER $\alpha$ and $A R$, only few miRNAs have been identified. These include miR-126-3p, which directly interacts with the PR 3'-UTR (Cui et al. 2011), and miR-124a, which binds to the GR 3'-UTR (Vreugdenhil et al. 2009), and potentially the MR 3'-UTR (Sober et al. 2010).

\section{IncRNAs and NRs}

It has long been known that lncRNAs can regulate NR transcriptional activity. In 1999, the steroid receptor RNA activator (SRA) was identified as the first lncRNA to bind and co-activate several NRs (Fig. 1Ci; Lanz et al. 1999). Subsequently, it was shown that lncRNA growth arrestspecific 5 (GAS5) was able to bind GR and negatively regulate its transcriptional activity by acting as a molecular decoy (Fig. 1Cii; Kino et al. 2010). Below we will discuss the key features of both IncRNAs and describe their currently known mechanisms of action.

Using a novel technique called global nuclear run-on and sequencing (GRO-seq) (Core et al. 2008), which allows genome-wide detection of nascent RNAs, Hah and colleagues gave the most detailed and comprehensive picture of the effect of estrogen on the global transcriptome of the ER $\alpha$-positive MCF-7 breast cancer cell line treated with $\mathrm{E}_{2}$ in a short-time course $(10,40$, and $160 \mathrm{~min})$.

Published by Bioscientifica Ltd. 
The authors showed that $\mathrm{E}_{2}$ regulates transcription by all three RNA polymerases (Hah et al. 2011). In addition to annotated protein coding and non-coding genes, they described an abundance of unannotated non-coding transcripts including divergent, enhancer, antisense, and intergenic transcripts whose expression is regulated by $\mathrm{E}_{2}$, indicating a role in $\mathrm{E}_{2}$-dependent transcription (Fig. 1D; Hah et al. 2011). Many of these transcripts were enhancer RNAs (eRNAs; Fig. 1Ciii), characterized by histone 3 lysine 4 monomethylation (H3K4me1) and the binding of the co-activator CBP, and whose expression correlates with the expression of nearby mRNAs (Kim et al. 2010). Several of the studies discussed below have, in recent years, focused on investigating the role and mode of action of eRNAs at enhancers of NR-regulated genes, although the exact mechanisms by which they promote transcription currently remain unclear.

\section{IncRNAs can bind to NRs and regulate their transcriptional activity}

lncRNAs can function as positive or negative regulators of NR-dependent transcription. SRA is a co-activator for several NRs (Lanz et al. 1999). It has been shown that multiple stem-loops in the SRA RNA are important for its coactivating function (Lanz et al. 2002). Several proteins have been shown to interact with SRA stem-loop structures, including the RNA pseudouridylate synthases PUS1P and PUS3P (pseudouridylation of SRA leads to enhanced coactivation of NRs (Zhao et al. 2004, 2007)), DEAD-box RNA helicases p68 and p72 (Watanabe et al. 2001), NR coactivator SRC1 (Lanz et al. 1999), as well as NR corepressors SHARP (Shi et al. 2001) and SLIRP (Hatchell et al. 2006). These findings led to the hypothesis that SRA may act as a 'scaffold' for the assembly of other co-regulatory proteins that direct NR-dependent transcription (Fig. 1Ci). More recently, by using a series of chemical-probing techniques Novikova et al. (2012) have determined the secondary structure of the entire SRA transcript. Since for many lncRNA molecules functionality depends on their secondary structure, characterization of this property will give important insights into the links between structure and function.

Connected to its role as a NR coactivator, SRA has been implicated in hormone-driven tumors such as breast and prostate cancers. It has been shown that SRA is overexpressed in breast tumors (Leygue et al. 1999, Murphy et al. 2000, Lanz et al. 2003) and that it affects the growth of breast and prostate cancer cell lines (Agoulnik \& Weigel 2009, Cooper et al. 2009). In vivo, transgenic mice overexpressing SRA show enhanced epithelial proliferation together with enhanced apoptosis, indicating that SRA could modulate homeostasis in epithelial tumors. However, in this study, the overexpression itself was not sufficient to induce tumorigenesis (Lanz et al. 2003).

Interestingly, although SRA1 was originally characterized as a regulatory ncRNA (Lanz et al. 1999), several coding isoforms that code for SRA protein (SRAP) have been identified (Emberley et al. 2003, Kawashima et al. 2003). This is one of a growing number of examples of bifunctional mRNAs that also exert coding-independent function as lncRNAs (Dinger et al. 2011).

In contrast to SRA, GAS5 acts as a negative regulator of GR transcription by a different mechanism. GAS5 directly interacts with the GR DBD and acts as a molecular decoy by competing with the glucocorticoid-response element for GR binding, thereby inhibiting GR-mediated transcription (Fig. 1Cii; Kino et al. 2010). In addition, Kino et al. (2010) showed that GAS5 accumulates in cells that have been starved of growth factors and by repressing GR activity, GAS5 sensitises cells to apoptosis. Since GR shares similar responsive elements with $\mathrm{AR}$, PR, and MR, GAS5 may also regulate these other steroid receptors. Furthermore, it has been shown that overexpression of GAS5 leads to growth arrest and apoptosis in human cell lines, including breast cancer cells, and its expression is significantly downregulated in breast tumors (Mourtada-Maarabouni et al. 2009).

Two lncRNAs, PCGEM1 and PRNCR1, overexpressed in aggressive forms of prostate cancer, directly interact with AR under ligand-stimulated conditions and sequentially interact with the receptor via specific posttranslational modification of the AR protein (Yang et al. 2013). However, these results have been contradicted by results from a later study (Prensner et al. 2014), which reported that neither PCGEM1 nor PRNCR1 is associated with castration-resistant prostate cancer, and that neither of them interact with AR, and the authors were also unable to find the post-translational modifications of IncRNAbound AR identified in the previous study (Prensner et al. 2014). Further studies are needed to resolve the discrepancies between these studies.

\section{NRs regulate IncRNAs with enhancer function}

The recent discovery that enhancer elements can be transcribed, resulting in the production of a novel class of ncRNA called eRNAs, has added yet more complexity to our understanding of regulated gene expression (Kim et al. 2010). Using RNA-seq together with ChIP-seq for RNA Pol II, Kim and colleagues showed that eRNAs are

Published by Bioscientifica Ltd. 
transcribed bidirectionally by RNA Pol II, and that their levels of expression correlate with those of neighboring mRNAs. This indicates that eRNAs are transcribed at enhancer elements that actively promote mRNA transcription. Initially identified in neurons (Kim et al. 2010), expression of eRNAs has subsequently been found in macrophages (De Santa et al. 2010), T-cells (Koch et al. 2011), and breast and prostate cancer cells (Hah et al. 2011, 2013, Wang et al. 2011, Li et al. 2013), indicating that transcription of eRNAs is a ubiquitous and abundant phenomenon.

Using GRO-seq, several groups have shown that eRNA expression is induced by external stimuli, such as hormones, as well as regulated by NRs. Hah and colleagues identified eRNAs at ER $\alpha$ enhancers as a class of noncoding transcripts regulated by $\mathrm{E}_{2}$ in MCF-7 cells. The vast majority of eRNAs showed upregulation upon $\mathrm{E}_{2}$ treatment, strongly indicating a positive function in the enhancer activation process (Hah et al. 2011). Similarly, GRO-seq was performed for the AR-positive LNCaP prostate cancer cell line treated with the hormone $5 \alpha$-dihydrotestosterone (DHT) to activate the $\mathrm{AR}$ (Wang et al. 2011). Just as $\mathrm{E}_{2}$ regulates the expression of eRNAs at enhancers of ER $\alpha$-regulated genes, DHT induces bidirectional transcription of eRNAs at enhancers of AR-regulated genes.

One question many groups have tried to resolve is whether the production and accumulation of eRNAs contribute to enhancer function, or are merely a byproduct of enhancer activation. Some have proposed that the act of transcription at enhancer elements may favor an open chromatin environment thereby promoting enhancer function, while others suggest that eRNAs may promote transcription by facilitating chromatin looping, which is an event that promotes a physical interaction between enhancers and target gene promoters (Orom et al. 2010, Orom \& Shiekhattar 2011, Natoli \& Andrau 2012). Hah and colleagues addressed this question within the context of ER $\alpha$-enhancer transcription. By integrating the previously performed GRO-seq together with a variety of existing genomic data sets from MCF-7 cells, including ChIP-seq, DNase-seq, and ChIA-PET, they determined that eRNAs at ER $\alpha$-binding sites positively correlate with the features of active enhancers (e.g., RNA Pol II, ER $\alpha$ coregulators, enhancer histone modifications H3K4me1, and $\mathrm{H} 3$ lysine 27 acetylation, H3K27ac), as well as enhancers looping to target genes (Hah et al. 2013). However, inhibition of eRNAs by the small molecule flavopiridol, a CDK9 inhibitor that blocks RNA Pol II transcription elongation, did not affect the assembly of $\mathrm{ER} \alpha$ enhancer complexes and did not affect $\mathrm{E}_{2}$-induced enhancer-promoter looping at ER $\alpha$-bound enhancers, indicating that eRNAs were not required for chromatin looping (Hah et al. 2013). However, by performing knockdown of eRNAs using both siRNAs and locked nucleic acid antisense oligonucleotides, Li et al. (2013) found strong inhibition of enhancer-promoter interaction and a concomitant decrease in expression of the coding gene regulated by that specific enhancer. Importantly, they demonstrated interaction of several eRNAs with the cohesin complex, which has been previously shown to be implicated in enhancer-promoter looping (Fig. 1Ciii; Kagey et al. 2010). The discrepancy between these two studies may be explained by the different techniques used (pharmacological inhibition of enhancer transcription versus eRNA knockdown) or may indicate different mechanisms acting at specific enhancers.

Results from recent studies of Rev-Erb enhancers in macrophages (Lam et al. 2013) and AR enhancers in LNCaP cells (Hsieh et al. 2014) have supported a functional role for eRNAs in enhancer-promoter looping and target gene activation. Further studies will certainly be required to clarify the role of eRNAs at enhancer sites.

\section{Conclusions}

NRs are key mediators of hormonal signals, with the responses they generate dependent on a variety of co-occurring factors and contexts. Dysregulation of these factors can generate pathological gene expression programs, as seen in breast and prostate cancers, as well as various metabolic syndromes. While the mechanisms by which miRNAs repress gene expression through $3^{\prime}$-UTR binding are now quite well understood, the diversity of mechanisms by which IncRNAs produce their effects continues to expand. As discussed in this review, miRNAs and IncRNAs have the capacity to regulate NR levels and activity, thereby affecting NR signaling, chromatin landscape and eventually transcription. Conversely, NRs can stimulate or repress ncRNA transcription (Fig. 1). Despite these recent discoveries, many questions still remain unanswered. In addition to the mechanisms described in this review, lncRNAs have been shown to act as epigenetic regulators by directly recruiting chromatin factors to specific genomic loci (Guttman et al. 2009, Mercer \& Mattick 2013). Indeed, the IncRNA HOTAIR is overexpressed and required for cell migration and invasion in metastatic ER $\alpha$-positive breast cancer cells (Gupta et al. 2010). Research is now focusing on identifying novel ncRNA players that can modulate NR signaling and unraveling their modes of action in normal cells, as well

Published by Bioscientifica Ltd. 
as in the disease setting. Given the importance of NRs in hormone-driven cancers, a deeper understanding of the crosstalk between these factors will have important therapeutic implications, including their potential utility as biomarkers or therapeutic targets.

\section{Declaration of interest}

The authors declare that there is no conflict of interest that could be perceived as prejudicing the impartiality of the review.

\section{Funding}

This work was supported by Action Against Cancer (AAC).

\section{Acknowledgements}

The authors wish to thank Prof. Simak Ali for critical reading of the manuscript.

\section{References}

Acevedo ML \& Kraus WL 2004 Transcriptional activation by nuclear receptors. Essays in Biochemistry 40 73-88.

Adams BD, Furneaux H \& White BA 2007 The micro-ribonucleic acid (miRNA) miR-206 targets the human estrogen receptor- $\alpha(\mathrm{ER} \alpha)$ and represses $\mathrm{ER} \alpha$ messenger RNA and protein expression in breast cancer cell lines. Molecular Endocrinology 21 1132-1147. (doi:10.1210/ me.2007-0022)

Adams BD, Claffey KP \& White BA 2009 Argonaute-2 expression is regulated by epidermal growth factor receptor and mitogen-activated protein kinase signaling and correlates with a transformed phenotype in breast cancer cells. Endocrinology 150 14-23. (doi:10.1210/ en.2008-0984)

Agoulnik IU \& Weigel NL 2009 Coactivator selective regulation of androgen receptor activity. Steroids 74 669-674. (doi:10.1016/ j.steroids.2009.02.007)

Ambs S, Prueitt RL, Yi M, Hudson RS, Howe TM, Petrocca F, Wallace TA, Liu CG, Volinia S, Calin GA et al. 2008 Genomic profiling of microRNA and messenger RNA reveals deregulated microRNA expression in prostate cancer. Cancer Research 68 6162-6170. (doi:10.1158/0008-5472.CAN-08-0144)

Bartel DP 2009 MicroRNAs: target recognition and regulatory functions. Cell 136 215-233. (doi:10.1016/j.cell.2009.01.002)

Batista PJ \& Chang HY 2013 Long noncoding RNAs: cellular address codes in development and disease. Cell 152 1298-1307. (doi:10.1016/j.cell. 2013.02.012)

Bazzini AA, Johnstone TG, Christiano R, Mackowiak SD, Obermayer B, Fleming ES, Vejnar CE, Lee MT, Rajewsky N, Walther TC et al. 2014 Identification of small ORFs in vertebrates using ribosome footprinting and evolutionary conservation. EMBO Journal 33 981-993. (doi:10.1002/embj.201488411)

Bernstein BE, Birney E, Dunham I, Green ED, Gunter C \& Snyder M 2012 An integrated encyclopedia of DNA elements in the human genome. Nature 489 57-74. (doi:10.1038/nature11247)

Bhat-Nakshatri P, Wang G, Collins NR, Thomson MJ, Geistlinger TR, Carroll JS, Brown M, Hammond S, Srour EF, Liu Y et al. 2009 Estradiol-regulated microRNAs control estradiol response in breast cancer cells. Nucleic Acids Research 37 4850-4861. (doi:10.1093/nar/ gkp500)
Birney E, Stamatoyannopoulos JA, Dutta A, Guigo R, Gingeras TR, Margulies EH, Weng Z, Snyder M, Dermitzakis ET, Thurman RE et al. 2007 Identification and analysis of functional elements in 1\% of the human genome by the ENCODE pilot project. Nature 447 799-816. (doi:10.1038/nature05874)

Brase JC, Johannes M, Schlomm T, Falth M, Haese A, Steuber T, Beissbarth T, Kuner R \& Sultmann H 2011 Circulating miRNAs are correlated with tumor progression in prostate cancer. International Journal Cancer $\mathbf{1 2 8}$ 608-616. (doi:10.1002/ijc.25376)

Carninci P, Kasukawa T, Katayama S, Gough J, Frith MC, Maeda N, Oyama R, Ravasi T, Lenhard B, Wells C et al. 2005 The transcriptional landscape of the mammalian genome. Science 309 1559-1563. (doi:10.1126/science.1112014)

Carroll JS, Liu XS, Brodsky AS, Li W, Meyer CA, Szary AJ, Eeckhoute J, Shao W, Hestermann EV, Geistlinger TR et al. 2005 Chromosomewide mapping of estrogen receptor binding reveals long-range regulation requiring the forkhead protein FoxA1. Cell 122 33-43. (doi:10.1016/j.cell.2005.05.008)

Carroll JS, Meyer CA, Song J, Li W, Geistlinger TR, Eeckhoute J, Brodsky AS, Keeton EK, Fertuck KC, Hall GF et al. 2006 Genome-wide analysis of estrogen receptor binding sites. Nature Genetics 38 1289-1297. (doi:10.1038/ng1901)

Castellano L, Giamas G, Jacob J, Coombes RC, Lucchesi W, Thiruchelvam P, Barton G, Jiao LR, Wait R, Waxman J et al. 2009 The estrogen receptor$\alpha$-induced microRNA signature regulates itself and its transcriptional response. PNAS 106 15732-15737. (doi:10.1073/pnas.0906947106)

Cheng C, Fu X, Alves P \& Gerstein M 2009 mRNA expression profiles show differential regulatory effects of microRNAs between estrogen receptor-positive and estrogen receptor-negative breast cancer. Genome Biology 10 R90. (doi:10.1186/gb-2009-10-9-r90)

Cheung E \& Kraus WL 2010 Genomic analyses of hormone signaling and gene regulation. Annual Review of Physiology 72 191-218. (doi:10.1146/annurev-physiol-021909-135840)

Cochrane DR, Cittelly DM \& Richer JK 2011 Steroid receptors and microRNAs: relationships revealed. Steroids 76 1-10. (doi:10.1016/ j.steroids.2010.11.003)

Cooper C, Guo J, Yan Y, Chooniedass-Kothari S, Hube F, Hamedani MK, Murphy LC, Myal Y \& Leygue E 2009 Increasing the relative expression of endogenous non-coding steroid receptor RNA activator (SRA) in human breast cancer cells using modified oligonucleotides. Nucleic Acids Research 37 4518-4531. (doi:10.1093/nar/gkp441)

Core LJ, Waterfall JJ \& Lis JT 2008 Nascent RNA sequencing reveals widespread pausing and divergent initiation at human promoters. Science 322 1845-1848. (doi:10.1126/science.1162228)

Cui W, Li Q, Feng L \& Ding W 2011 MiR-126-3p regulates progesterone receptors and involves development and lactation of mouse mammary gland. Molecular and Cellular Biochemistry 355 17-25. (doi:10.1007/ s11010-011-0834-1)

Denayer S, Helsen C, Thorrez L, Haelens A \& Claessens F 2010 The rules of DNA recognition by the androgen receptor. Molecular Endocrinology 24 898-913. (doi:10.1210/me.2009-0310)

De Santa F, Barozzi I, Mietton F, Ghisletti S, Polletti S, Tusi BK, Muller H, Ragoussis J, Wei CL \& Natoli G 2010 A large fraction of extragenic RNA pol II transcription sites overlap enhancers. PLoS Biology 8 e1000384. (doi:10.1371/journal.pbio.1000384)

Dinger ME, Gascoigne DK \& Mattick JS 2011 The evolution of RNAs with multiple functions. Biochimie 93 2013-2018. (doi:10.1016/j.biochi. 2011.07.018)

Djebali S, Davis CA, Merkel A, Dobin A, Lassmann T, Mortazavi A, Tanzer A, Lagarde J, Lin W, Schlesinger F et al. 2012 Landscape of transcription in human cells. Nature 489 101-108. (doi:10.1038/nature11233)

Emberley E, Huang GJ, Hamedani MK, Czosnek A, Ali D, Grolla A, Lu B, Watson PH, Murphy LC \& Leygue E 2003 Identification of new human coding steroid receptor RNA activator isoforms. Biochemical and Biophysical Research Communications 301 509-515. (doi:10.1016/ S0006-291X(02)03070-X) 
Fabian MR, Sonenberg N \& Filipowicz W 2010 Regulation of mRNA translation and stability by microRNAs. Annual Review of Biochemistry 79 351-379. (doi:10.1146/annurev-biochem-060308-103103)

Fletcher CE, Dart DA, Sita-Lumsden A, Cheng H, Rennie PS \& Bevan CL 2012 Androgen-regulated processing of the oncomir miR-27a, which targets Prohibitin in prostate cancer. Human Molecular Genetics 21 3112-3127. (doi:10.1093/hmg/dds139)

Gadaleta RM \& Magnani L 2014 Nuclear receptors and chromatin: an inducible couple. Journal of Molecular Endocrinology 52 R137-R149. (doi:10.1530/JME-13-0170)

Gandellini P, Folini M, Longoni N, Pennati M, Binda M, Colecchia M, Salvioni R, Supino R, Moretti R, Limonta P et al. 2009 miR-205 exerts tumor-suppressive functions in human prostate through downregulation of protein kinase Cepsilon. Cancer Research 69 2287-2295. (doi:10.1158/0008-5472.CAN-08-2894)

Gregory PA, Bert AG, Paterson EL, Barry SC, Tsykin A, Farshid G, Vadas MA, Khew-Goodall Y \& Goodall GJ 2008 The miR-200 family and miR-205 regulate epithelial to mesenchymal transition by targeting ZEB1 and SIP1. Nature Cell Biology 10 593-601. (doi:10.1038/ncb1722)

Gupta RA, Shah N, Wang KC, Kim J, Horlings HM, Wong DJ, Tsai MC, Hung T, Argani P, Rinn JL et al. 2010 Long non-coding RNA HOTAIR reprograms chromatin state to promote cancer metastasis. Nature 464 1071-1076. (doi:10.1038/nature08975)

Guttman M \& Rinn JL 2012 Modular regulatory principles of large non-coding RNAs. Nature 482 339-346. (doi:10.1038/nature10887)

Guttman M, Amit I, Garber M, French C, Lin MF, Feldser D, Huarte M, Zuk O, Carey BW, Cassady JP et al. 2009 Chromatin signature reveals over a thousand highly conserved large non-coding RNAs in mammals. Nature 458 223-227. (doi:10.1038/nature07672)

Guttman M, Russell P, Ingolia NT, Weissman JS \& Lander ES 2013 Ribosome profiling provides evidence that large noncoding RNAs do not encode proteins. Cell 154 240-251. (doi:10.1016/j.cell.2013. 06.009)

Hah N, Danko CG, Core L, Waterfall JJ, Siepel A, Lis JT \& Kraus WL 2011 A rapid, extensive, and transient transcriptional response to estrogen signaling in breast cancer cells. Cell 145 622-634. (doi:10.1016/j.cell. 2011.03.042)

Hah N, Murakami S, Nagari A, Danko CG \& Kraus WL 2013 Enhancer transcripts mark active estrogen receptor binding sites. Genome Research 23 1210-1223. (doi:10.1101/gr.152306.112)

Hatchell EC, Colley SM, Beveridge DJ, Epis MR, Stuart LM, Giles KM, Redfern AD, Miles LE, Barker A, MacDonald LM et al. 2006 SLIRP, a small SRA binding protein, is a nuclear receptor corepressor. Molecular Cell 22 657-668. (doi:10.1016/j.molcel.2006.05.024)

Heldring N, Isaacs GD, Diehl AG, Sun M, Cheung E, Ranish JA \& Kraus WL 2011 Multiple sequence-specific DNA-binding proteins mediate estrogen receptor signaling through a tethering pathway. Molecular Endocrinology 25 564-574. (doi:10.1210/me.2010-0425)

Helsen C \& Claessens F 2014 Looking at nuclear receptors from a new angle. Molecular and Cellular Endocrinology 382 97-106. (doi:10.1016/ j.mce.2013.09.009)

Helsen C, Kerkhofs S, Clinckemalie L, Spans L, Laurent M, Boonen S, Vanderschueren D \& Claessens F 2012 Structural basis for nuclear hormone receptor DNA binding. Molecular and Cellular Endocrinology 348 411-417. (doi:10.1016/j.mce.2011.07.025)

Helwak A, Kudla G, Dudnakova T \& Tollervey D 2013 Mapping the human miRNA interactome by CLASH reveals frequent noncanonical binding. Cell 153 654-665. (doi:10.1016/j.cell.2013.03.043)

Hirose T, Mishima Y \& Tomari Y 2014 Elements and machinery of non-coding RNAs: toward their taxonomy. EMBO Reports 15 489-507. (doi:10.1002/embr.201338390)

Hsieh CL, Fei T, Chen Y, Li T, Gao Y, Wang X, Sun T, Sweeney CJ, Lee GS, Chen $S$ et al. 2014 Enhancer RNAs participate in androgen receptordriven looping that selectively enhances gene activation. PNAS 111 7319-7324. (doi:10.1073/pnas.1324151111)
Hulf T, Sibbritt T, Wiklund ED, Patterson K, Song JZ, Stirzaker C, Qu W, Nair S, Horvath LG, Armstrong NJ et al. 2013 Epigenetic-induced repression of microRNA-205 is associated with MED1 activation and a poorer prognosis in localized prostate cancer. Oncogene 32 2891-2899. (doi:10.1038/onc.2012.300)

Kagey MH, Newman JJ, Bilodeau S, Zhan Y, Orlando DA, van Berkum NL, Ebmeier CC, Goossens J, Rahl PB, Levine SS et al. 2010 Mediator and cohesin connect gene expression and chromatin architecture. Nature 467 430-435. (doi:10.1038/nature09380)

Kapranov P, Cheng J, Dike S, Nix DA, Duttagupta R, Willingham AT, Stadler PF, Hertel J, Hackermuller J, Hofacker IL et al. 2007 RNA maps reveal new RNA classes and a possible function for pervasive transcription. Science 316 1484-1488. (doi:10.1126/science.1138341)

Kawashima H, Takano H, Sugita S, Takahara Y, Sugimura K \& Nakatani T 2003 A novel steroid receptor co-activator protein (SRAP) as an alternative form of steroid receptor RNA-activator gene: expression in prostate cancer cells and enhancement of androgen receptor activity. Biochemical Journal 369 163-171. (doi:10.1042/BJ20020743)

Kerkhofs S, Dubois V, De Gendt K, Helsen C, Clinckemalie L, Spans L, Schuit F, Boonen S, Vanderschueren D, Saunders PT et al. 2012 A role for selective androgen response elements in the development of the epididymis and the androgen control of the $5 \alpha$ reductase II gene. FASEB Journal 26 4360-4372. (doi:10.1096/fj.11-202283)

Kim TK, Hemberg M, Gray JM, Costa AM, Bear DM, Wu J, Harmin DA, Laptewicz M, Barbara-Haley K, Kuersten S et al. 2010 Widespread transcription at neuronal activity-regulated enhancers. Nature 465 182-187. (doi:10.1038/nature09033)

Kino T, Hurt DE, Ichijo T, Nader N \& Chrousos GP 2010 Noncoding RNA Gas5 is a growth arrest- and starvation-associated repressor of the glucocorticoid receptor. Science Signaling 3 ra8. (doi:10.1126/scisignal. 2000568)

Koch F, Fenouil R, Gut M, Cauchy P, Albert TK, Zacarias-Cabeza J, Spicuglia S, de la Chapelle AL, Heidemann M, Hintermair C et al. 2011 Transcription initiation platforms and GTF recruitment at tissue-specific enhancers and promoters. Nature Structural \& Molecular Biology 18 956-963. (doi:10.1038/nsmb.2085)

Krol J, Loedige I \& Filipowicz W 2010 The widespread regulation of microRNA biogenesis, function and decay. Nature Reviews. Genetics 11 597-610. (doi:10.1038/nrg2843)

Lai CF, Flach KD, Alexi X, Fox SP, Ottaviani S, Thiruchelvam PT, Kyle FJ, Thomas RS, Launchbury R, Hua $\mathrm{H}$ et al. 2013 Co-regulated gene expression by oestrogen receptor $\alpha$ and liver receptor homolog- 1 is a feature of the oestrogen response in breast cancer cells. Nucleic Acids Research 41 10228-10240. (doi:10.1093/nar/gkt827)

Lam MT, Cho H, Lesch HP, Gosselin D, Heinz S, Tanaka-Oishi Y, Benner C, Kaikkonen MU, Kim AS, Kosaka M et al. 2013 Rev-Erbs repress macrophage gene expression by inhibiting enhancer-directed transcription. Nature 498 511-515. (doi:10.1038/nature12209)

Lanz RB, McKenna NJ, Onate SA, Albrecht U, Wong J, Tsai SY, Tsai MJ \& O'Malley BW 1999 A steroid receptor coactivator, SRA, functions as an RNA and is present in an SRC-1 complex. Cell 97 17-27. (doi:10.1016/S0092-8674(00)80711-4)

Lanz RB, Razani B, Goldberg AD \& O’Malley BW 2002 Distinct RNA motifs are important for coactivation of steroid hormone receptors by steroid receptor RNA activator (SRA). PNAS 99 16081-16086. (doi:10.1073/pnas.192571399)

Lanz RB, Chua SS, Barron N, Soder BM, DeMayo F \& O'Malley BW 2003 Steroid receptor RNA activator stimulates proliferation as well as apoptosis in vivo. Molecular and Cellular Biology 23 7163-7176. (doi:10.1128/MCB.23.20.7163-7176.2003)

Lee Y, Kim M, Han J, Yeom KH, Lee S, Baek SH \& Kim VN 2004 MicroRNA genes are transcribed by RNA polymerase II. EMBO Journal $\mathbf{2 3}$ 4051-4060. (doi:10.1038/sj.emboj.7600385)

Leivonen SK, Makela R, Ostling P, Kohonen P, Haapa-Paananen S, Kleivi K, Enerly E, Aakula A, Hellstrom K, Sahlberg N et al. 2009 Protein lysate microarray analysis to identify microRNAs regulating estrogen receptor 
signaling in breast cancer cell lines. Oncogene 28 3926-3936. (doi:10.1038/onc.2009.241)

Lewis BP, Burge CB \& Bartel DP 2005 Conserved seed pairing, often flanked by adenosines, indicates that thousands of human genes are microRNA targets. Cell 120 15-20. (doi:10.1016/j.cell.2004.12.035)

Leygue E, Dotzlaw H, Watson PH \& Murphy LC 1999 Expression of the steroid receptor RNA activator in human breast tumors. Cancer Research 59 4190-4193.

Li W, Notani D, Ma Q, Tanasa B, Nunez E, Chen AY, Merkurjev D, Zhang J, Ohgi K, Song X et al. 2013 Functional roles of enhancer RNAs for oestrogen-dependent transcriptional activation. Nature 498 516-520. (doi:10.1038/nature12210)

Magny EG, Pueyo JI, Pearl FM, Cespedes MA, Niven JE, Bishop SA \& Couso JP 2013 Conserved regulation of cardiac calcium uptake by peptides encoded in small open reading frames. Science $\mathbf{3 4 1}$ 1116-1120. (doi:10.1126/science.1238802)

Mangelsdorf DJ, Thummel C, Beato M, Herrlich P, Schutz G, Umesono K, Blumberg B, Kastner P, Mark M, Chambon P et al. 1995 The nuclear receptor superfamily: the second decade. Cell $\mathbf{8 3} 835-839$. (doi:10.1016/0092-8674(95)90199-X)

Matera AG, Terns RM \& Terns MP 2007 Non-coding RNAs: lessons from the small nuclear and small nucleolar RNAs. Nature Reviews. Molecular Cell Biology 8 209-220. (doi:10.1038/nrm2124)

Mercer TR \& Mattick JS 2013 Structure and function of long noncoding RNAs in epigenetic regulation. Nature Structural \& Molecular Biology 20 300-307. (doi:10.1038/nsmb.2480)

Mitchell PS, Parkin RK, Kroh EM, Fritz BR, Wyman SK, PogosovaAgadjanyan EL, Peterson A, Noteboom J, O’Briant KC, Allen A et al. 2008 Circulating microRNAs as stable blood-based markers for cancer detection. PNAS 105 10513-10518. (doi:10.1073/pnas.0804549105)

Mourtada-Maarabouni M, Pickard MR, Hedge VL, Farzaneh F \& Williams GT 2009 GAS5, a non-protein-coding RNA, controls apoptosis and is downregulated in breast cancer. Oncogene 28 195-208. (doi:10.1038/ onc.2008.373)

Murphy LC, Simon SL, Parkes A, Leygue E, Dotzlaw H, Snell L, Troup S, Adeyinka A \& Watson PH 2000 Altered expression of estrogen receptor coregulators during human breast tumorigenesis. Cancer Research 60 6266-6271.

Natoli G \& Andrau JC 2012 Noncoding transcription at enhancers: general principles and functional models. Annual Review of Genetics 46 1-19. (doi:10.1146/annurev-genet-110711-155459)

Novikova IV, Hennelly SP \& Sanbonmatsu KY 2012 Structural architecture of the human long non-coding RNA, steroid receptor RNA activator. Nucleic Acids Research 40 5034-5051. (doi:10.1093/nar/gks071)

Orom UA \& Shiekhattar R 2011 Noncoding RNAs and enhancers: complications of a long-distance relationship. Trends in Genetics 27 433-439. (doi:10.1016/j.tig.2011.06.009)

Orom UA, Derrien T, Beringer M, Gumireddy K, Gardini A, Bussotti G, Lai F, Zytnicki M, Notredame C, Huang Q et al. 2010 Long noncoding RNAs with enhancer-like function in human cells. Cell 143 46-58. (doi:10.1016/j.cell.2010.09.001)

Ostling P, Leivonen SK, Aakula A, Kohonen P, Makela R, Hagman Z, Edsjo A, Kangaspeska S, Edgren H, Nicorici D et al. 2011 Systematic analysis of microRNAs targeting the androgen receptor in prostate cancer cells. Cancer Research 71 1956-1967. (doi:10.1158/0008-5472.CAN-10-2421)

Ozen M, Creighton CJ, Ozdemir M \& Ittmann M 2008 Widespread deregulation of microRNA expression in human prostate cancer. Oncogene 27 1788-1793. (doi:10.1038/sj.onc.1210809)

Pauli A, Norris ML, Valen E, Chew GL, Gagnon JA, Zimmerman S, Mitchell A, Ma J, Dubrulle J, Reyon D et al. 2014 Toddler: an embryonic signal that promotes cell movement via Apelin receptors. Science 3431248636. (doi:10.1126/science.1248636)

Pinho FG, Frampton AE, Nunes J, Krell J, Alshaker H, Jacob J, Pellegrino L, Roca-Alonso L, de Giorgio A, Harding V et al. 2013 Downregulation of microRNA-515-5p by the estrogen receptor modulates sphingosine kinase 1 and breast cancer cell proliferation. Cancer Research 73 5936-5948. (doi:10.1158/0008-5472.CAN-13-0158)

Porkka KP, Pfeiffer MJ, Waltering KK, Vessella RL, Tammela TL \& Visakorpi T 2007 MicroRNA expression profiling in prostate cancer. Cancer Research 67 6130-6135. (doi:10.1158/0008-5472.CAN-07-0533)

Prensner JR, Sahu A, Iyer MK, Malik R, Chandler B, Asangani IA, Poliakov A, Vergara IA, Alshalalfa M, Jenkins RB et al. 2014 The lncRNAs PCGEM1 and PRNCR1 are not implicated in castration resistant prostate cancer. Oncotarget 30 1434-1438.

Rainer J, Ploner C, Jesacher S, Ploner A, Eduardoff M, Mansha M, Wasim M, Panzer-Grumayer R, Trajanoski Z, Niederegger H et al. 2009 Glucocorticoid-regulated microRNAs and mirtrons in acute lymphoblastic leukemia. Leukemia 23 746-752. (doi:10.1038/leu.2008.370)

Renthal NE, Chen CC, Williams KC, Gerard RD, Prange-Kiel J \& Mendelson CR 2010 miR-200 family and targets, ZEB1 and ZEB2, modulate uterine quiescence and contractility during pregnancy and labor. PNAS 107 20828-20833. (doi:10.1073/pnas.1008301107)

Ribas J, Ni X, Haffner M, Wentzel EA, Salmasi AH, Chowdhury WH, Kudrolli TA, Yegnasubramanian S, Luo J, Rodriguez R et al. 2009 miR-21: an androgen receptor-regulated microRNA that promotes hormonedependent and hormone-independent prostate cancer growth. Cancer Research 69 7165-7169. (doi:10.1158/0008-5472.CAN-09-1448)

Rinn JL \& Chang HY 2012 Genome regulation by long noncoding RNAs. Annual Review of Biochemistry 81 145-166. (doi:10.1146/annurevbiochem-051410-092902)

Ross-Innes CS, Stark R, Holmes KA, Schmidt D, Spyrou C, Russell R, Massie CE, Vowler SL, Eldridge M \& Carroll JS 2010 Cooperative interaction between retinoic acid receptor- $\alpha$ and estrogen receptor in breast cancer. Genes and Development 24 171-182. (doi:10.1101/ gad.552910)

Sahu B, Laakso M, Ovaska K, Mirtti T, Lundin J, Rannikko A, Sankila A, Turunen JP, Lundin M, Konsti J et al. 2011 Dual role of FoxA1 in androgen receptor binding to chromatin, androgen signalling and prostate cancer. EMBO Journal 30 3962-3976. (doi:10.1038/emboj. 2011.328)

Shi Y, Downes M, Xie W, Kao HY, Ordentlich P, Tsai CC, Hon M \& Evans RM 2001 Sharp, an inducible cofactor that integrates nuclear receptor repression and activation. Genes and Development 15 1140-1151. (doi:10.1101/gad.871201)

Shi XB, Xue L, Yang J, Ma AH, Zhao J, Xu M, Tepper CG, Evans CP, Kung HJ \& deVere White RW 2007 An androgen-regulated miRNA suppresses Bak1 expression and induces androgen-independent growth of prostate cancer cells. PNAS 104 19983-19988. (doi:10.1073/pnas.0706641104)

Shin C, Nam JW, Farh KK, Chiang HR, Shkumatava A \& Bartel DP 2010 Expanding the microRNA targeting code: functional sites with centered pairing. Molecular Cell 38 789-802. (doi:10.1016/j.molcel.2010.06.005)

Sober S, Laan M \& Annilo T 2010 MicroRNAs miR-124 and miR-135a are potential regulators of the mineralocorticoid receptor gene (NR3C2) expression. Biochemical and Biophysical Research Communications 391 727-732. (doi:10.1016/j.bbrc.2009.11.128)

Vreugdenhil E, Verissimo CS, Mariman R, Kamphorst JT, Barbosa JS, Zweers T, Champagne DL, Schouten T, Meijer OC, de Kloet ER et al. 2009 MicroRNA 18 and 124a down-regulate the glucocorticoid receptor: implications for glucocorticoid responsiveness in the brain. Endocrinology 150 2220-2228. (doi:10.1210/en.2008-1335)

Waltering KK, Porkka KP, Jalava SE, Urbanucci A, Kohonen PJ, Latonen LM, Kallioniemi OP, Jenster G \& Visakorpi T 2011 Androgen regulation of micro-RNAs in prostate cancer. Prostate 71 604-614. (doi:10.1002/ pros.21276)

Wang Q, Li W, Liu XS, Carroll JS, Janne OA, Keeton EK, Chinnaiyan AM, Pienta KJ \& Brown M 2007 A hierarchical network of transcription factors governs androgen receptor-dependent prostate cancer growth. Molecular Cell 27 380-392. (doi:10.1016/j.molcel.2007.05.041)

Wang D, Garcia-Bassets I, Benner C, Li W, Su X, Zhou Y, Qiu J, Liu W, Kaikkonen MU, Ohgi KA et al. 2011 Reprogramming transcription by 
distinct classes of enhancers functionally defined by eRNA. Nature $\mathbf{4 7 4}$ 390-394. (doi:10.1038/nature10006)

Wapinski O \& Chang HY 2011 Long noncoding RNAs and human disease. Trends in Cell Biology 21 354-361. (doi:10.1016/j.tcb.2011. 04.001)

Watanabe M, Yanagisawa J, Kitagawa H, Takeyama K, Ogawa S, Arao Y, Suzawa M, Kobayashi Y, Yano T, Yoshikawa H et al. 2001 A subfamily of RNA-binding DEAD-box proteins acts as an estrogen receptor $\alpha$ coactivator through the N-terminal activation domain (AF-1) with an RNA coactivator, SRA. EMBO Journal 20 1341-1352. (doi:10.1093/ emboj/20.6.1341)

Wendler A, Keller D, Albrecht C, Peluso JJ \& Wehling M 2011 Involvement of let-7/miR-98 microRNAs in the regulation of progesterone receptor membrane component 1 expression in ovarian cancer cells. Oncology Reports 25 273-279. (doi:10.3892/or_00001071)

Xia HF, Jin XH, Song PP, Cui Y, Liu CM \& Ma X 2010 Temporal and spatial regulation of miR-320 in the uterus during embryo implantation in the rat. International Journal of Molecular Sciences 11 719-730. (doi:10.3390/ ijms11020719)

Xiao J, Gong AY, Eischeid AN, Chen D, Deng C, Young CY \& Chen XM 2012 miR-141 modulates androgen receptor transcriptional activity in human prostate cancer cells through targeting the small heterodimer partner protein. Prostate 72 1514-1522. (doi:10.1002/ pros.22501)
Xiao X, Wang P \& Chou KC 2013 Recent progresses in identifying nuclear receptors and their families. Current Topics in Medicinal Chemistry 13 1192-1200. (doi:10.2174/15680266113139990006)

Yang L, Lin C, Jin C, Yang JC, Tanasa B, Li W, Merkurjev D, Ohgi KA, Meng D, Zhang J et al. 2013 lncRNA-dependent mechanisms of androgen-receptor-regulated gene activation programs. Nature $\mathbf{5 0 0}$ 598-602. (doi:10.1038/nature12451)

Zechel C, Shen XQ, Chambon P \& Gronemeyer H 1994 The dimerization interfaces formed between the DNA binding domains determine the cooperative binding of RXR/RAR and RXR/TR heterodimers to DR5 and DR4 elements. EMBO Journal 13 1414-1424.

Zhao X, Patton JR, Davis SL, Florence B, Ames SJ \& Spanjaard RA 2004 Regulation of nuclear receptor activity by a pseudouridine synthase through posttranscriptional modification of steroid receptor RNA activator. Molecular Cell 15 549-558. (doi:10.1016/j.molcel.2004.06.044)

Zhao X, Patton JR, Ghosh SK, Fischel-Ghodsian N, Shen L \& Spanjaard RA 2007 Pus3p- and Pus1p-dependent pseudouridylation of steroid receptor RNA activator controls a functional switch that regulates nuclear receptor signaling. Molecular Endocrinology 21 686-699. (doi:10.1210/me.2006-0414)

Zhao JJ, Lin J, Yang H, Kong W, He L, Ma X, Coppola D \& Cheng JQ 2008 MicroRNA-221/222 negatively regulates estrogen receptor $\alpha$ and is associated with tamoxifen resistance in breast cancer. Journal of Biological Chemistry 283 31079-31086. (doi:10.1074/jbc.M806041200)

Received in final form 16 July 2014

Accepted 24 July 2014

Accepted Preprint published online 25 July 2014 http://jme.endocrinology-journals.org DOI: 10.1530/JME-14-0134
() 2014 Society for Endocrinology Printed in Great Britain
Published by Bioscientifica Ltd 